\title{
Acclimatization and flower induction of tissue culture derived cocoyam (Xanthosoma sagittifolium Schott) plants
}

\author{
OU Onokpise ${ }^{1}$, JT Tambong ${ }^{2}$, L Nyochembeng ${ }^{2}$, JG Wutoh ${ }^{3}$ \\ Florida A \& M University, 'Division of Agricultural Sciences, Tallahassee, FL 32307, USA; \\ ${ }^{2}$ Institute of Agronomic Research (IRA), Ekona, PMB 25, Buea; \\ ${ }^{3} I R A$, Root and Tubers Research Project (ROTREP) Ekona, PMB 25, Buea, Cameroon
}

(Received 22 March 1991; accepted 10 January 1992)

\begin{abstract}
Summary - Explants (shoot tips) were obtained for production of tissue culture plants, from cocoyam (Xanthosoma sagittifolium) plants growing in agroecological zone II (Cameroon) at the Root and Tubers Research Project (ROTREP) Biotechnology Laboratory at the Ekona Research Center. In order to utilize these tissue-culture derived plants (TCP) for field work, procedures for their acclimatization were developed. Three hundred plantlets were randomly selected from the first batch of 500 plantlets produced by ROTREP and acclimatized using 4 different growth media: i), sterilized vermiculite and sterilized top soil (SVMS, 50:50); ii), unsterilized vermiculite and unsterilized top soil (NSVMS, 50:50); iii), sterilized top soil (SS, $100 \%$ ); and iv), unsterilized top soil (NSS, 100\%). From the successfully acclimatized plants, 200 plants were taken for artificial flower induction studies. Gibberellic acid $\left(\mathrm{GA}_{3}\right)$ was sprayed on the tissue culturederived cocoyam plants (TCP) at different concentrations $(0,500,750,1000,1500$ parts per million) for flower induction. There were no significant differences in growth of plantlets raised in the NSS medium and in the other growth media. Mean petiole length was in fact highest for plants acclimatized in NSS. Thus soil sterilization may not be critical for acclimatization of cocoyam plantlets. This is an important factor in the humid tropics, where resources are limited. Initial growth of plants was best for $\left(\mathrm{GA}_{3}\right)$ sprayed compared to unsprayed plants. The highest number of inflorescences as well as pollen quantity was obtained at 750 and $1000 \mathrm{ppm}$. Growth was significantly correlated with days to bracts and spadix formation. Flowering of tissue culture derived plants occurred 20-30 days earlier than that reported for non-tissue culture derived plants.
\end{abstract}

Xanthosoma sagittifolium / cocoyam / malanga / inflorescence / gibberellic acid / top soil / vermiculite / acclimatization

Résumé - Acclimatation et induction florale chez le malanga (Xanthosoma sagittifolium) produit à partir de culture de tissu. Afin d'utiliser des plants obtenus par culture de tissus (TCP) pour un travail en champ, nous avons développé des procédures d'acclimatation de ces plants. Les explants de malanga (Xanthosoma sagittifolium), destinés à la production de plants par culture de tissus au laboratoire de biotechnologie du Centre de recherche d'Ekona (projet de recherche sur les racines et tubercules ROTREP); provenaient du Cameroun, zone agroécologique 11. Trois cents plantules, parmi le premier lot de 500 produit par ROTREP, furent choisies au hasard et acclimatées en utilisant 4 différents milieux de culture:

- vermiculite stérilisée et sol superficiel stérilisé (SVMS 50:50);

- vermiculite et sol superficiel non stériles (NSVMS 50:50);

- sol superficiel stérilisé (SS 100\%);

- sol superficiel non stérile (NSS 100\%).

Deux cents plantes furent prélevées parmi les plantes acclimatées pour l'étude de l'induction florale. De l'acide gibbérellique $\left(G A_{3}\right)$ à différentes concentrations $(0,500,750,1000,1500$ ppm) fut pulvérisé sur 
les plantules. Aucune différence de croissance significative ne fut observée entre les plantules obtenues dans les différents milieux de culture. La longueur moyenne du pétiole était cependant plus importante pour les plantules cultivées sur NSS. Nous en déduisons que la stérilisation du sol n'est pas un élément critique pour l'acclimatation de plantules de malanga. Ceci est important dans les zones tropicales humides où les ressources sont limitées. La croissance initiale des plantules fut meilleure pour les plantes traitées au $\mathrm{GA}_{3}$ que pour les plantes non traitées. Les meilleurs résultats en nombre d'inflorescences et en quantité de pollen furent obtenus pour des doses de 750 et 1000 ppm. La croissance fut significativement corrélée à la date d'apparition des bractées et du spadice. La floraison de plantes issues de culture de tissus eut lieu $20-30 j$ plus tôt que celle de plantes normales.

Xanthosoma sagittifolium $=$ malanga $/$ inflorescence $/$ acide gibbérellique $/$ sol superficiel $/$ vermicu lite / acclimatation

\section{INTRODUCTION}

Cocoyams (Xanthosoma spp and Colocosia spp) are an important group of tropical root crops providing energy for over 300 million people worldwide, mostly in the tropics (Lyonga and Nzietchueng, 1987). In Cameroon, cocoyams (Xanthosoma sagittifolium) are one of the most important root crops, only surpassed by cassava (Manihot esculenta Crantz) (Lyonga, 1980; Besong, 1989).

However, there has been a progressive production decline in this root crop in Cameroon and elsewhere in the tropics, attributable to a root-rot disease, the principal causal agent of which is Pythium myriotylum (Nzietcheung, 1985; Lyogna and Nzietchueng, 1987; Adams et al, 1988). Only limited success has been achieved to date in breeding for resistance against this disease due to the lack of breeding methodologies. A few clones derived from initial hybrids (Agueguia and Nzietchueng, 1984; Agueguia, 1988) have been evaluated for their resistance to the root-rot disease (Agueguia and Onokpise, 1990). Flower production still remains a severe limiting factor for cocoyam breeding and selection.

Although several researchers have reported artificial flower induction of cocoyam plants using gibberellic acid $\left(\mathrm{GA}_{3}\right)$ (McDavid and Alamu, 1976; Alamu and McDavid, 1978; Wilson, 1979; Agueguia and Nzietchueng 1984; Alamu et $a l, 1982$ ) the varied results make it difficult to select an optimum $\mathrm{GA}_{3}$ concentration induction.

Furthermore, virtually all the studies reported have been carried out on cocoyam clones derived from field or greenhousegrown plants rather than tissue-culture plants. Flower induction has also been carried out during the rainy season in order to enhance flower production (Wilson, 1979; Agueguia, personal communication). This limits breeding strategy to only 1 period during the growing season. Although there have been reports on cocoyam (Xanthosoma) explant culture (Lalopua, 1988), little or no information exists on the acclimatization of plantlets resulting from such cultures, even though acclimatization consitutes a critical phase of tissue culture. Preliminary studies to compare the performances of plantlets placed in planticons and black plastic greenhouse pots showed better results in the latter than in the former.

The objectives of these studies were: i), to identify the most suitable media or medium for successful acclimatization of tissue culture derived cocoyam plants; ii), to induce flowering and obtain optimum gibberellic acid $\left(G_{3}\right)$ levels for flower induction of tissue culture derived cocoyam plants. To the best of our knowledge, work on artificial induction of flowers from tissue culture derived cocoyam plants has not previously been reported.

\section{MATERIALS AND METHODS}

\section{Derivation of tissue culture plants (TCP)}

Shoot tips were harvested from cocoyam plants at the 3-5 leaf stage randomly collected from various locations in the southwest province of Cameroon. 
Occasionally cocoyam tubers were grown in the greenhouse for 5-6 weeks to provide young shoot tips. The average size of the shoot tips ranged from $0.5-2.5 \mathrm{~cm}$. Once harvested, shoot tips were surface-sterilized by immersing them in $5 \%$ chlorox solution for 5-10 min after initial cleaning in distilled water. Following immersion in chlorox, shoot tips were rinsed in sterilized double-distilled water for $5 \mathrm{~min}$.

Liquid media (Wutoh and Brooks, unpublished observations) for culturing cocoyam shoot tips was prepared by modifying the basic B5 medium of Gamborg et al (1968) (table I). This modified medium contained no growth regulators. For culturing, prepared liquid medium was poured into test tubes $(15 \times 2 \mathrm{~cm})$ so that the tubes were one-third filled. The test tubes were then sterilized at $121^{\circ} \mathrm{C}$ and $15 \mathrm{PSI}$ for $20 \mathrm{~min}$. Shoot tips (explants) were then transferred to the test tubes containing the liquid medium. Cultures were then moved into a walk-in Labconco growth chamber where they were incubated under $16 \mathrm{~h}$ light $/ 8 \mathrm{~h}$ dark photoperiod with average day/night temperatures of $28^{\circ} \mathrm{C} / 24^{\circ} \mathrm{C}$ respectively. Incubation period was 4-6 weeks, during which time the shoot tips produced cocoyam tissue culture plantlets.

\section{Acclimatization of tissue culture-derived plants}

Three hundred plantlets were randomly selected for acclimatization studies. These plantlets were then divided into 4 groups of 75 plants each and transferred directly from test tubes into perforated polythene bags $(20 \times 15 \mathrm{~cm})$ containing the following growth substrates:

- Group I: unsterilized soil (NSS);

Table I. Composition of the cocoyam culture medium.

\section{Compound}

Amount $(g / l)$

\begin{tabular}{|c|c|}
\hline $\mathrm{KNO}_{3}$ & 2.500 \\
\hline $\mathrm{NaH}_{2} \mathrm{PO}_{4} \cdot \mathrm{H}_{2} \mathrm{O}$ & 0.150 \\
\hline$\left(\mathrm{NH}_{4}\right) 2 \mathrm{SO}_{4}$ & 0.134 \\
\hline $\mathrm{MgSO}_{4} \cdot 7 \mathrm{H}_{2} \mathrm{O}$ & 0.250 \\
\hline $\mathrm{CaCl}_{2} \cdot 2 \mathrm{H}_{2} \mathrm{O}$ & 0.15 \\
\hline $\mathrm{MnSO}_{4} \cdot 2 \mathrm{H}_{2} \mathrm{O}$ & 0.01 \\
\hline $\mathrm{H}_{3} \mathrm{BO}_{4}$ & $3 \times 10^{-3}$ \\
\hline $\mathrm{ZnSO}_{4} \cdot 7 \mathrm{H}_{2} \mathrm{O}$ & $2 \times 10^{-2}$ \\
\hline KI & 0.75 \\
\hline $\mathrm{Na}_{2} \mathrm{Mo}_{4} \cdot 2 \mathrm{H}_{2} \mathrm{O}$ & 0.25 \\
\hline $\mathrm{CoCl}_{2} \cdot 6 \mathrm{H}_{2} \mathrm{O}$ & $2.5 \times 10^{-5}$ \\
\hline $\mathrm{CuSO}_{4} \cdot 7 \mathrm{H}_{2} \mathrm{O}$ & $2.5 \times 10^{-5}$ \\
\hline $\mathrm{FeSO}_{4}$ & 0.0278 \\
\hline $\mathrm{Na}_{2} \mathrm{EDTA}$ & 0.033 \\
\hline Sucrose & 30 \\
\hline
\end{tabular}

- Group II: unsterilized vermiculite + unsterilized soil (NSVMS) mixed at a ratio of 50:50;

- Group III: sterilized vermiculite + sterilized soil (SVMS) mixed at a ratio of 50:50;

- Group IV: sterilized soil (SS).

The top soil used for this study was obtained from our cocoyam germplasm nursery at Mamu, Ekona, Cameroon. Sterilization of top soil and vermiculite mixes as well as top soil alone was performed at $121^{\circ} \mathrm{C}, 15 \mathrm{PSI}$ for $15 \mathrm{~min}$ using prefabricated sterilized bags $(70 \times 40 \times 60 \mathrm{~cm})$.

All transferred plantlets (2-leaf-stage and $10 \mathrm{~cm}$ in height) in the perforated black polythene bags $(20 \times 10 \times 15 \mathrm{~cm})$ were covered with transparent plastic bags $(10 \times 5 \times 10 \mathrm{~cm})$ (to avoid wilting) and placed on a tissue culture rack where they were allowed to grow for 3 days prior to being moved outside the ROTREP biotechnology laboratory. The physical conditions on the rack were $24-28^{\circ} \mathrm{C}$ under $16 / 8 \mathrm{~h}$ day/night photoperiod, while outside the laboratory the temperature was $27.5^{\circ} \mathrm{C}$ with a $12 / 12 \mathrm{~h}$ photoperiod. The plants were watered every 3 days with ordinary tap water.

\section{Flower induction of acclimatized plants}

From the successfully acclimatized plants, 200 plants were taken and divided into 2 groups (A and B) of 100 plants each. Group A plants were taken to a greenhouse maintained at $29^{\circ} \mathrm{C}$ under $12 \mathrm{~h}$ day/night conditions. The second group of plants (group B) were allowed to grow in the walk-in growth chamber at $28-30^{\circ} \mathrm{C}$ under $16 / 8 \mathrm{~h}$ day/night conditions. Within each group, plants were subdivided into groups of 20 and subjected to gibberellic acid $\left(\mathrm{GA}_{3}\right)$ treatment using 5 different concentrations of $0,500,750$, 1000,1500 parts per million respectively, at the 4-5-leaf stage. This took place 7 weeks after successful acclimatization. A $1 \%$ solution of a surfactant (Tween 20) was added to $\mathrm{GA}_{3}$ preparations as wetting agent. This concentration ensured that the $\mathrm{GA}_{3}$ reached leaf cells without being washed off by watering or rainfall. Leaves were sprayed to the point of run-off and filling of the cup formed by the petiole bases.

All plants (groups $A$ and $B$ ) were later transferred to 16-I pots filled with top soil and moved to an outside environment close to the ROTREP Biotechnology Laboratory. This was done 4 weeks after plants had been sprayed with $\mathrm{GA}_{3}$. The average temperature of the outside environment was $27^{\circ} \mathrm{C}\left(81^{\circ} \mathrm{F}\right)$. Plants were fertilized at monthly intervals with available liquid fertilizer $\left(\left(\mathrm{NH}_{4}\right)_{2} \mathrm{SO}_{4}\right.$, $1000 \mathrm{ppm}$ ) to ensure vigorous growth. 


\section{Data collected}

Survival rates, petiole length and number of leaves per plant were measured; days to bract observation, spadix production, total number of inflorescence (bracts and spadices) per plant and pollen production were recorded for data on flowering. Survival rates were determined at 2,4 , and 6 weeks after potted plants had been moved from the growth chamber to the culture rack and outside the biotechnology laboratory. Petiole length was determined biweekly by direct measurement of individual petioles from ground level to the basal lobes of the leaf. Pollen production was obtained by a score rating of 0 to $2(0=$ no pollen, $1=$ profuse, 2 = very profuse). Plants were harvested for yield (cormels and corm numbers, and cormel weight) at 17 weeks after $\mathrm{GA}_{3}$ treatment.

\section{RESULTS AND DISCUSSION}

The survival rate of acclimated plantlets was $100 \%$ in each of the 4 types of growth substrate recorded at 2, 4, and 6 weeks after transfer from test tubes. This indicates that for tissue culture cocoyam (Xanthosoma sagittifolium) plantlets, soil sterilization is not essential for their acclimation, especially as the unsterilized soil (NSS) provided higher mean petiole lengths (fig 1). Lalopua (1988) reported abnormalities when plants were transferred into unsterilized soil medium, and proposed that soil sterilization be carried out to eliminate soil-borne bacteria which were considered to be the principal cause of these abnormalities. However, in the present study such abnormalities were not observed.

The rate of growth was lower for plantlets raised in sterilized soil (SS) (fig 1). This may be attributed to the loss of microorganisms during heat sterilization. As a result the plant used up the existing nutrients for normal growth rate for 3 weeks, after which the nutrients became limited. The superiority of NSS can be attributed to its better water retention, sufficient nutrient availability and adequate microbial activity in spite of a slight depression regarding growth rate observed during the third week. Although a few weeds appeared on unsterilized soil mixtures (NSS and NSVMS) 2 weeks earlier than SVmSS, this did not constitute a critical problem.
The good performance of the soil/vermiculite mixture (fig 1) was probably due to the modification of the structure and texture of the soil by the addition of a soil conditioner which aids in regulation of gaseous diffusion from and into the atmosphere, retention and movement of water, and also stimulates root proliferation and development. However, due to the additional costs involved in the use of vermiculite, unsterilized soil (NSS) still remains the best alternative. This is indeed the case in regions where limited resources hamper the use of plant biotechnology procedures for crop improvement and productivity. No significant difference was observed between performance of group A and B plants.

Plants which were subjected to gibberellic acid $\left(\mathrm{GA}_{3}\right)$ treatment showed faster growth than untreated plants during the first 7-9 weeks after treatment (fig $2 a, 2 b$ ). Initial increase in plant growth may have been due to a response to the growth regulator. $\mathrm{GA}_{3}$ treatment of cocoyam has been known to result in internode elongation of cocoyam stolons

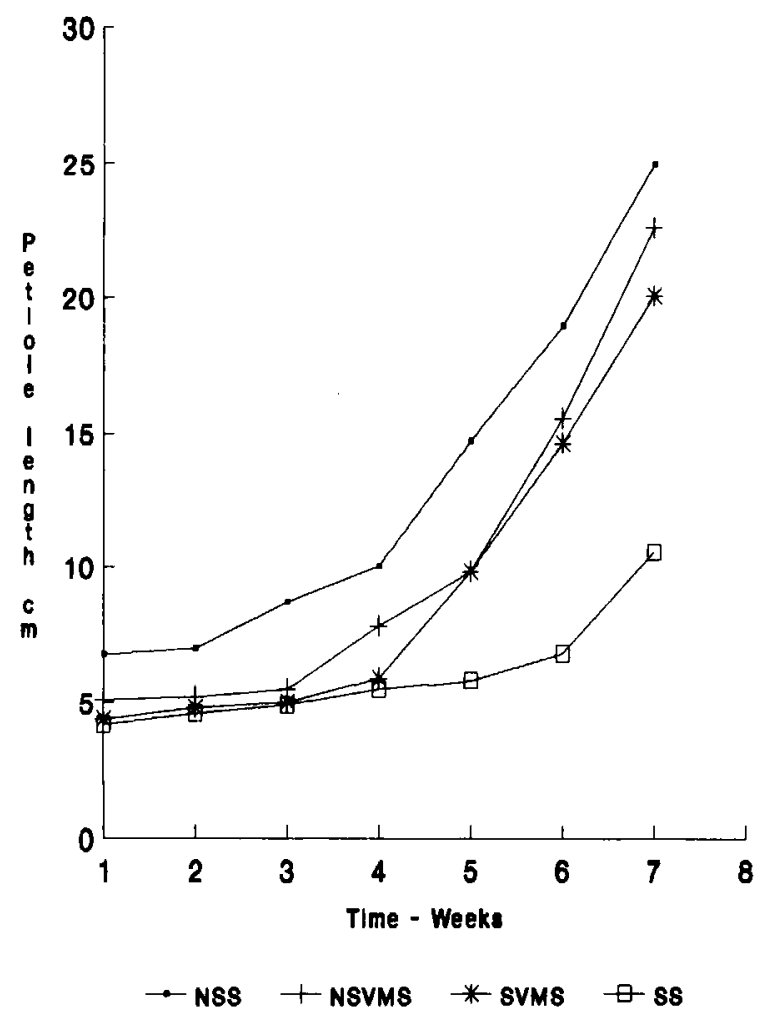

Fig 1. Effect of the different soil mixture on the growth of cocoyam plantlets. NSS = unsterilized soil; NSVMS = unsterilized vermiculite + unsterilized soil; SVMS = sterilized vermiculite + sterilized soil; SS = sterilized soil. 

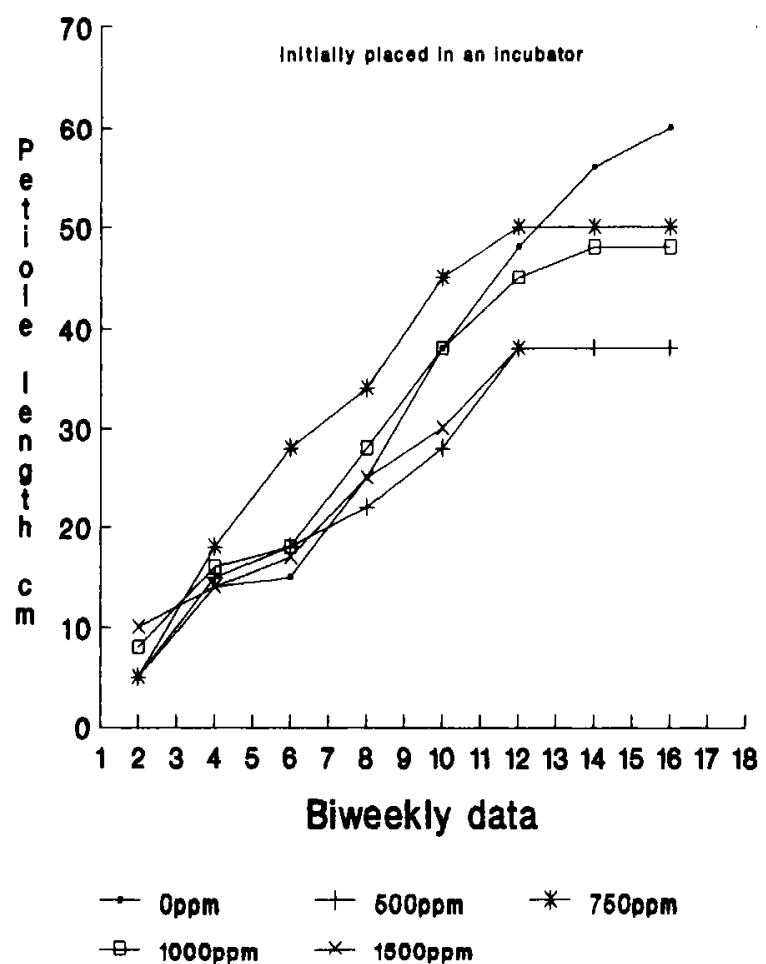

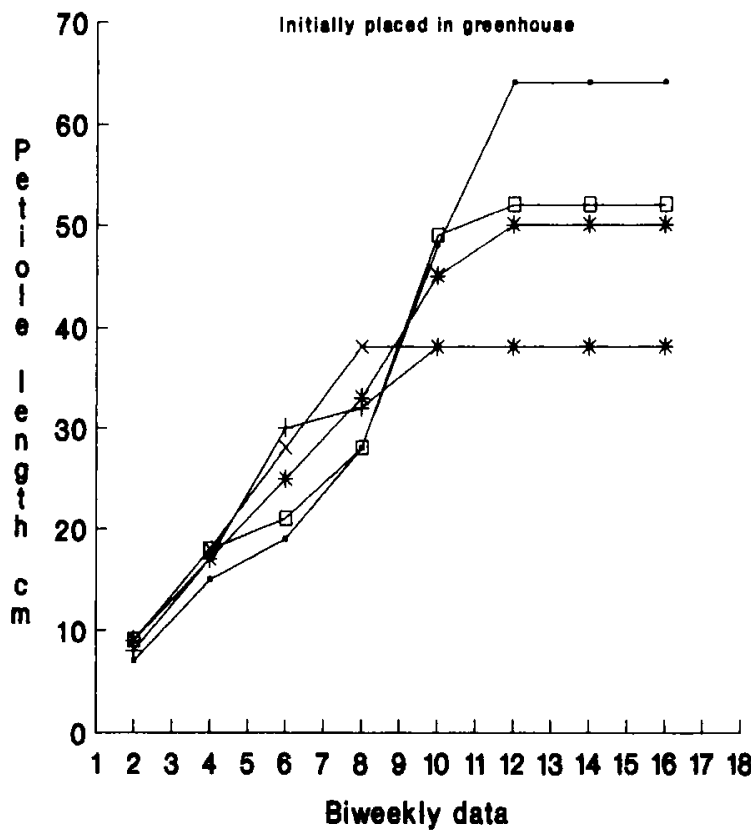

$\rightarrow$ 00pm $\quad+600 \mathrm{ppm} \quad * 750 \mathrm{ppm}$
$\square$ t000ppm $\quad * 1500 \mathrm{ppm}$

Fig 2. Effect of gibberellic acid treatment on the growth of tissue culture derived cocoyam plants. (A) Tissue culturederived cocoyam plants initially placed in an incubator; (B) tissue culture-derived cocoyam plants initially placed in a greenhouse.

(Alamu and McDavid, 1978). Concentrations of 750 and $1000 \mathrm{ppm}$ had similar growth rates which were significantly higher than for 500 and 1500 ppm respectively.

Days to flowering as indicated by bract and spadix formation were similar for all treatments (table II). The first indications of flowering (bracts) were observed at 50 to 82 days for all treatments and 75 to 90 days for spadix formation. Although days to bract and spadix formation were quite similar, the total number of inflorescences produced by plants treated with 750 and $1000 \mathrm{ppm}$ was significantly higher than that produced at 500 and $1500 \mathrm{ppm}$ respectively (table III). The quantity and quality of flowers produced by a plant are very important for hybridization purposes. Therefore it may be necessary to spray cocoyam plants with $\mathrm{GA}_{3}$ at 750 and $1000 \mathrm{ppm}$. Due to the similarity of results at these 2 concentrations, $750 \mathrm{ppm}$ was chosen for economic reasons.

It should be noted that the days to the formation of reproductive structures observed in this study were 20-30 days earlier than those reported for non-tissue culture derived plants where the average number of days to flower- ing is 70 to 120 (Alamu and McDavid, 1978; Wilson, 1979; Alamu et al, 1982; Agueguia and Nzietchung, 1984). The tissue culture derived plants may have a lower endogenous level of $\mathrm{GA}_{3}$, and spraying them with an artificial source may have provided an optimum level of gibberellic acid for vegetative and reproductive growth.

Table II. Effect of gibberellic acid $\left(\mathrm{GA}_{3}\right)$ treatment on days $s^{\star}$ to bract and spadix formation in tissue culture-derived cocoyam plants.

\begin{tabular}{rccccc}
\hline \multirow{2}{*}{$\begin{array}{c}\text { Gibber } \\
\text { elic acid } \\
\text { conc } \\
\text { (ppm) }\end{array}$} & TC plants outside & & \multicolumn{2}{c}{$\begin{array}{c}\text { TC plants in } \\
\text { incubators }\end{array}$} \\
\cline { 2 - 3 } \cline { 5 - 6 } & Bracts & Spadix & & Bracts & Spadix \\
\hline 0 & $0^{\mathrm{a}^{\star \star}}$ & $0^{\mathrm{a}}$ & & $0^{\mathrm{a}}$ & $0^{\mathrm{a}}$ \\
500 & $50^{\mathrm{b}}$ & $75^{\mathrm{b}}$ & & $60^{\mathrm{b}}$ & $79^{\mathrm{b}}$ \\
750 & $50^{\mathrm{b}}$ & $75^{\mathrm{b}}$ & & $62^{\mathrm{b}}$ & $75^{\mathrm{b}}$ \\
1000 & $50^{\mathrm{b}}$ & $75^{\mathrm{b}}$ & & $60^{\mathrm{b}}$ & $75^{\mathrm{b}}$ \\
1500 & $51^{\mathrm{b}}$ & $90^{\mathrm{c}}$ & & $82^{\mathrm{c}}$ & $90^{\mathrm{c}}$ \\
\hline
\end{tabular}

Days on which flowering structures were first observed (mean of 20 plants). * Plants kept in old greenhouse. All plants (incubator and greenhouse) were moved to an outside environment at $27.2^{\circ} \mathrm{C}\left(81^{\circ} \mathrm{F}\right)$ at 4 weeks. ${ }^{* *}$ Values within a column followed by different letters are significantly different at 5\% Duncan's multiple range test. 
Correlation coefficients calculated for 8 parameters (table IV) showed that the total number of cormels was significantly, but negatively correlated with the number of bracts formed and cormel weight respectively. If cormel weight is regarded as a measure of size, the fewer the cormels that are produced the bigger the cormels would be. Physiologically this is to be expected, since the accumulation of food reserves on fewer cormels increases their size (weight) compared to many centers in which these reserves might otherwise have been distributed. Positive and significant correlations were also obtained for days to spadix formation and growth. This appears to indicate that rapid vegetative growth is associated with flowering if plants have been sprayed with gibberellic acid, in particular at $750 \mathrm{ppm}$.

Table III. Total number of bracts and spadices produced 17 weeks after gibberellic acid treatment of tissue culture derived cocoyam plants.

\begin{tabular}{ccccc}
\hline $\begin{array}{c}\text { Gibberellic } \\
\text { acid } \\
\begin{array}{c}\text { concentration } \\
(p p m)\end{array}\end{array}$ & \multicolumn{2}{c}{$\begin{array}{c}\text { TC plants } \\
\text { outside }\end{array}$} & \multicolumn{2}{c}{$\begin{array}{c}\text { TC plants } \\
\text { in incubator }\end{array}$} \\
\cline { 2 - 5 } & Bracts & Spadix & Bracts & Spadix \\
\hline 0 & 0 & 0 & 0 & 0 \\
500 & $9^{\mathrm{a}^{* *}}$ & $3^{\mathrm{a}}$ & $14^{\mathrm{a}}$ & $2^{\mathrm{a}}$ \\
750 & $37^{\mathrm{b}}$ & $22(2)^{\mathrm{b}^{* * *}}$ & $38^{\mathrm{b}}$ & $20(2)^{\mathrm{b}}$ \\
1000 & $33^{\mathrm{b}}$ & $18(1)^{\mathrm{b}}$ & $37^{\mathrm{b}}$ & $12(1)^{\mathrm{c}}$ \\
1500 & $18^{\mathrm{c}}$ & $1^{\mathrm{a}}$ & $14^{\mathrm{a}}$ & $6^{\mathrm{a}}$ \\
\hline
\end{tabular}

* Plants kept in the greenhouse, all plants (incubator and greenhouse) were moved to an outside environment $\left(81^{\circ} \mathrm{F}-27.7^{\circ} \mathrm{C}\right)$ at 4 weeks. ${ }^{* *}$ Values within a column followed by different letters are significantly different at $5 \%$ Duncan's multiple range test. ${ }^{* *}$ Mean pollen score in parentheses: 1 = profuse; 2 = very profuse. Scoring for pollen production was recorded for only 750 and $1000 \mathrm{ppm}$ GA-treated plants.
These studies indicate that tissue culture derived cocoyam plants provide results similar to those of non-tissue culture derived cocoyams in a similar environment. An attempt should therefore be made to utilize these new techniques so that maximum productivity is attained in these parts of the world.

\section{ACKNOWLEDGMENTS}

Funds were provided by the US Agency for International Development (USAID) under project No 631-0058, and the Government of the Republic of Cameroon (GRC) for these studies has been gratefully acknowledged. We thank the executive committee of the Roots and Tubers Research Project (ROTREP) for logistic support given to OU Onokpise during his 2year tour of duty with ROTREP. Special thanks go to $J$ Mbake for technical assistance, to $M$ Sheihk and SK Pancholy Division of Agricultural Sciences, Florida $A$ and $M$ University, for invaluable advice, and to our anonymous reviewers and journal editor for critical review of the original manuscript.

\section{REFERENCES}

Adams H, Pattanjalidial, Brown G, Cooper B, Clarke A (1988) Aroid improvement in the eastern Caribbean: an update of the Aroid/Arrow root crop project. 7th Symp Int Soc Tropical Root Crops, Gosier, Guadeloupe, 1-6 July 1985. INRA, Paris 1988

Table IV. Correlation coefficients for some vegetative, reproductive and yield characters of cocoyam treated with $750 \mathrm{ppm}$ gibberellic acid.

\begin{tabular}{llllllllll}
\hline & & 1 & 2 & 3 & 4 & 5 & 6 & 7 & 8 \\
\hline 1 & Db & 1.00 & 1.00 & $0.89^{*}$ & 0.38 & 0.49 & 0.32 & 0.43 & 0.78 \\
2 & Ds & & 1.00 & $0.95^{*}$ & 0.39 & 0.37 & 0.35 & 0.41 & 0.43 \\
3 & Gr & & & 1.00 & 0.48 & 0.05 & 0.12 & 0.13 & 0.57 \\
4 & \#b & & & & 1.00 & 0.28 & $0.87^{*}$ & 0.71 & 0.27 \\
5 & \#s & & & & & 1.00 & 0.30 & 0.63 & 0.73 \\
6 & Cn & & & & & & 1.00 & $0.87^{*}$ & 0.50 \\
7 & Cw & & & & & & & 1.00 & 0.50 \\
8 & Ps & & & & & & & & \\
\hline
\end{tabular}

$\mathrm{Db}=$ days to bract formation; $\mathrm{Ds}=$ days to spadix formation; $\mathrm{Gr}=$ growth (petiole length); \#b = total number of bracts; $\# S=$ total number of spadices; $\mathrm{C} n=$ cormel number; $\mathrm{CW}=$ cormel weight; $\mathrm{PS}=$ pollen score; ${ }^{*}$ significant at $P=0.05$. 
Aguegia A (1990) Progress in cocoyam (Xanthosoma sagittifolium) breeding in Cameroon, 1979 to 1987. In: Proc VIII Symp Int Soc Tropical Root Crops, Bangkok, Thailand, Oct 30 - Nov 5, 1988, 648654

Agueguia A, Nzietchueng S (1984) Production of hybrid Xanthosoma sagittifolium and test for resistance to Pythium myriotylum. In: Tropical Root Crops. Production and Uses in Africa (Terry ER, Doku EV, Arene OB, Mahungu NM, eds) Proc 2nd Triennial Symp Int Soc Tropical Root Crops, Africa Branch, Douala, Cameroon. IDRC, Ottawa, Canada, 221, 169-171

Agueguia A, Onokpise OU (1990) Evaluation of cocoyam (Xantosoma sagittifolium) clones for root rot blight complex resistance. Indian J Genet \& Plant Breed 50(3) (in press)

Alamu S, McDavid CR (1978) Production of flowering in edible aroids by gibberellic acid. Trop Agric (Trinidad) 55(1) 81-86

Alamu S, McDavid CR, Duncan EJ (1982) Production of viable gibberellic acid-treated tannia (Xanthosoma sagittifolium) plants. Trop Agric (Trinidad) 59 (4) 323-334
Gamborg OL, Miller RA, Ojima K (1968) Nutrient requirements of suspension cultures of soybean root cells. Exp Cell Res 50 151-158

Lalopua JR (1988) Crop potential of unexploited tuberous plants. Ambon Fac Agric, Pattimura University, Indonesia (submitted to United States Agency for Int Dev)

Lyonga SN (1980) Cocoyam production in Cameroon. Symp Taro and Cocoyam, Stockholm, Sweden. IFS Prov Rep No 5

Lyonga SN Nzietchueng S (1987) Cocoyam and the African food crisis. Root Crops and the African Food Crisis (Terry ER, Akoroda MO, Arene DB, eds) Proc 3rd Triennial Symp Int Soc Tropical Root Crops, African Branch. (Akoroda MO, Arene DB eds) IDRC, Ottawa, Ontario, Canada, 258 84-88

McDavid CR, Alamu S (1976) Promotion of flowering in tannia (Xanthosoma sagittifolium) by gibberellic acid. Trop Agric (Trinidad) 53, 373-374

Wilson JE (1979) Cocoyam Breeding by Flower Induction, Pollination and Germination. Manual Ser No 4, IITA, Ibadan, Nigeria 